International Journal of Agriculture, Environment and Bioresearch

Vol. 5, No. 05; 2020

ISSN: $2456-8643$

\title{
THE ROLE OF PROTECTIVE EFFECT OF ZINGERON IN GENE EXPRESSIOON AGAINST GENOTOXIC EFFECT OF 2,4-D ISOOCTYLESTER HERBICIDE ON WHEAT TYPES
}

\author{
Hüseyin BULUT ${ }^{1}$ and Nalan YILDIRIM DOĞAN ${ }^{2}$ \\ ${ }^{1}$ Erzincan Binali Yıldırım University, Vocational School of Health Services, 24100 Erzincan / Turkey \\ ${ }^{2}$ Erzincan Binali Yıldırım University, Department of Biology, Faculty of Science and Arts, 24100 Erzincan / Turkey
}

https://doi.org/10.35410/IJAEB.2020.5567

\begin{abstract}
Combating pests that cause more than $50 \%$ of annual food production to disappear has become increasingly important. Pesticides used against agricultural pests play an essential role in increasing the yield. However, pesticides lead to various problems such as deterioration of ecological balance, contamination of nutrients, and increase of environmental pollution depending on the frequency of use. These substances, which have a genotoxic effect, can irreversibly change the structure or gene expression of DNA. Different plant extracts have been used in different organisms to determine the protective effects of natural antioxidants to reduce or prevent the effect of toxins. In our study, the protective effect of zingerone against the genotoxic effect caused by the 2,4-D isooctylester herbicide was investigated in Sönmez-2001, Köprü and Altay-2000 wheat types. For this, 14-3-3 defense protein gene expression analysis were performed. Our study results have revealed that 2,4-D isooctylester herbicide causes the least stress in Sönmez-2001 and the most in Altay-2000 type. From the data obtained from our study, it has been determined that zingerone has a protective effect against herbicide stress.
\end{abstract}

Keywords: 2,4-D Isooctylester, Gene expression, Genotoxic effect, Herbicides, Triticum aestivum, Zingerone.

\section{INTRODUCTION}

Anthropogenic activities may play an important role in the disruption of the world ecological balance. For instance, the size of agricultural land sown in our country for the last 10 years has decreased from 39.122 thousand hectares to 37.817 thousand hectares. On the other hand, in the same period, the populations of Turkey increased from 71 million to 82 million (TSI,2019). With the effect of these factors, it is necessary to obtain more products from more areas (Rastogi etal., 2017; Moreno-González etal.,2017; Malarkodi et al., 2017; Cheng et al., 2017). The change in agriculture areas in recent years in our country is given in Figure 1. 


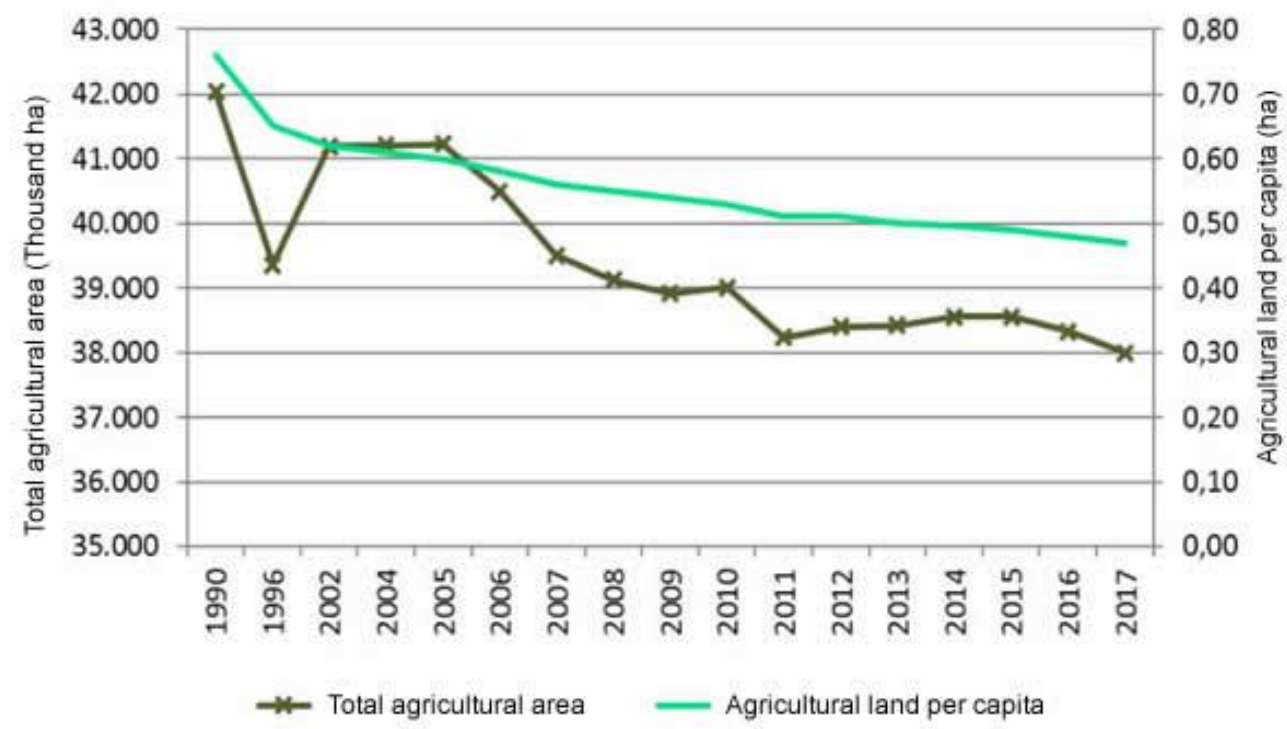

Figure 1. Total and per capita agricultural area

Diseases, insects, and undesired plants have an important share in the yield loss of plants. The most significant share in the fight against loss of efficiency is the fight against chemical drugs. The total amount of pesticide usage in Turkey rose to 54.098 tons in 2017, with an increase of $8.08 \%$ compared to 2016. Fungicides consisted $44 \%$ of the total pesticide use in 2017. This is followed by insecticides with $22.8 \%$, herbicides with $23.5 \%$, acaricides with $4.9 \%$, rodenticides with $0.5 \%$ and others with $12.4 \%$ (EUM, 2019). In recent years, the use of pesticides has been gradually increasing and Erzincan ranks 58th with $46.389 \mathrm{~kg} / \mathrm{lt}$ in 81 provinces in pesticide use and 44th with $1.046 \mathrm{~kg} / \mathrm{lt}$ in herbicide use. Types and amounts of pesticides used in Erzincan are given in detail in Table 1 (AFM, 2020).

Table 1.The amounts of pesticides used in Erzincan

\begin{tabular}{|llllllll|}
\hline & $\begin{array}{l}\text { Insecticides } \\
(\mathrm{kg}-\mathrm{lt})\end{array}$ & $\begin{array}{l}\text { Fungicides } \\
(\mathrm{kg}-\mathrm{lt})\end{array}$ & $\begin{array}{l}\text { Herbicides } \\
(\mathrm{kg}-\mathrm{lt})\end{array}$ & $\begin{array}{l}\text { Acaricide } \\
(\mathrm{kg}-\mathrm{lt})\end{array}$ & $\begin{array}{l}\text { Rodendisit+ } \\
\text { Mollusit } \\
(\mathrm{kg}-\mathrm{lt})\end{array}$ & $\begin{array}{l}\text { Other } \\
(\mathrm{kg}- \\
\mathrm{lt})\end{array}$ & $\begin{array}{l}\text { Total } \\
(\mathrm{kg}-\mathrm{lt})\end{array}$ \\
\hline Erzincan 2.798 \\
\hline $\begin{array}{l}\text { Other } \\
\text { Attractant+Fumigant+Nematicide }\end{array}$
\end{tabular}

Depending on the frequency of use of pesticides, residue problems in soil, water and foodstuffs, acute and chronic poisoning, deterioration of ecological balance, adverse effects on non-target organisms, and contamination of nutrients are observed (Avc1, 2009).

Considering the amount of production and planting area in the world, the most preferred agricultural product group is cereals. Today, approximately half of the cultivated soils are used 
for cereal production (Köksel et al., 2000). Wheat and wheat products form the basis of carbohydrates taken in daily nutrition and supply most of the daily energy. Complex carbohydrates such as wheat, starch and fiber are among the best and most economical sources. $20 \%$ of the protein need of 4.5 billion people in 94 developing countries in the world is met by wheat products (Brenchley et al., 2012). Turkey is one of the countries that consume most wheat and wheat products in the world. According to the United Nations Food and Agriculture Organization (FAO) statistics, the annual consumption per capita in Turkey is $173.5 \mathrm{~kg}$. In comparison, the annual per capita consumption of wheat products in European Union countries is $102.9 \mathrm{~kg}$. According to 2016 data, cereal production is carried out on an area of 11.6 million hectares in our country. While, in $65.3 \%$ of this area, wheat is produced, barley is produced in $24.1 \%$ and corn in $6.3 \%$. These products are followed by rye $(1.2 \%)$, paddy $(0.9 \%)$, oats $(0.8 \%)$ and triticale $(0.3 \%)$ production (TSI, 2016).

In this study, the potential protective role of the ginger extract zingerone against the genotoxic effect of 2,4-D isooctylester herbicide on wheat cultivation of Triticum aestivum (Liu et al., 2005), which is one of the model organisms such as Hordeum vulgare, Allium cepa, Zea mays, Vicia faba and Arabidopsis thaliana used for the detection of genotoxic effect in recent years, has been investigated via defense gene expression level.

\section{MATERIALS AND METHODS}

Material: Pure race one-year Köprü, Sönmez-2001, Altay-2000 wheat seeds obtained from NBC Agriculture and Seed Growing (Eskişehir) were sterilized with $\mathrm{NaOCl}$ and dried. Seeds of equal size were placed in petri dishes and germinated with water at $25^{\circ} \mathrm{C}$. The experimental group was formed by adding 2,4-D isooctylester in $0.1 \mathrm{ppm}, 0.2 \mathrm{ppm}, 0.3 \mathrm{ppm}, 0.4 \mathrm{ppm}$ and $0.5 \mathrm{ppm}$ doses to the germinated seeds, and $0 \mathrm{ppm}, 0.1 \mathrm{ppm}, 0.2 \mathrm{ppm}$ and $0.3 \mathrm{ppm}$ zingerone for each dose. 2,4$\mathrm{D}$ isooctyl ester and zingerone were given periodically to the growing seedlings. Seedlings, which were germinated only with water and did not contain 2,4-D isooctyl ester and zingerone, formed the control group. All the samples were allowed to grow at $25{ }^{\circ} \mathrm{C}(70 \%$ relative humidity).

Germinated Köprü, Sönmez-2001 and Altay-2000 samples were collected at the end of 14 days according to ISTA seed applications and were kept at $-80{ }^{\circ} \mathrm{C}$ after being cleaned from external pollution.

mRNA isolation. After putting the roots and leaves of wheat samples by liquid nitrogen in dust, RNA isolation was performed by Ribospin Plant 307-150 kit in accordance with the instructions of the manufacturer.

cDNA synthesis. cDNA synthesis The master mix $2 \mu 1$ for the first step of cDNA synthesis from the RNA obtained was prepared by being completed with ultrapure water so as to be $1 \mu \mathrm{l}$ primer, $1 \mu \mathrm{dNTP}$ up to a total volume of $14 \mu \mathrm{l}$ and left for $5 \mathrm{~min}$ at $65^{\circ} \mathrm{C}$. Then, the second master mix for the samples taken onto the ice was prepared in quantities as $2 \mu 109$ RTase reaction buffer, 2 $\mu 10.1$ M DTT, $1 \mu 1$ Hyper ScriptTM Reverse Transcriptase (200 $\mu \mathrm{l})$ and $1 \mu 1$ ZymAllTM RNase Inhibitor, and $6 \mu 1$ hereof was added as per sample. The Samples were respectively incubated for $60 \mathrm{~min}$ at $55^{\circ} \mathrm{C}$ and $5 \mathrm{~min}$ at $85^{\circ} \mathrm{C}$. 
RT-PCR analysis. Primers Ta14S1, Ta14S2 and $\beta$-actin for wheat were designed for gene expression of the 14-3-3 protein family. $\beta$-actin has been used as the housekeeping gene. The details pertaining to the primers employed are provided in Table 2 . The synthesized cDNAs, primers Ta14S1, Ta14S2 have been checked by using PCR analysis primer $\beta$-actin (GenBank ID: AB181991.1) has been used as reference. All real-time PCR samples have been executed in 3 repetitions. In RT-PCR analysis, cDNAs diluted at the rate of 1:200 have been used as templates. The RTPCR reaction components and the schedule belonging to reaction temperature cycle are given below. All reactions have been performed on the Bioneer Exicycler 96_ (Bioneer, South Korea). PCR components and Amplification parameters are presented below.

$10 \mu \mathrm{l}$ of $2 \mathrm{X}$ SYBR master mix was prepared at the rates of $0.8 \mu \mathrm{F}$ (forward) $(10 \mathrm{pm})$ primer, $0.8 \mu 1 \mathrm{R}$ (reverse) (10 pm) primer, $2 \mu 1 \mathrm{ROX}, 4 \mu \mathrm{cDNA}$, and $2.4 \mu 1$ ultrapure water and added to the loading wells. By loading $4 \mu \mathrm{l}$ cDNA samples onto them, RT-PCR was carried out at 95 ${ }^{\circ} \mathrm{C}$ for $10 \mathrm{~min}$ and at $95^{\circ} \mathrm{C}$ for 45 cycles in $15 \mathrm{~s}$ and at $60{ }^{\circ} \mathrm{C}$ for 45 cycles in $1 \mathrm{~min}$.

Table 2. Primers used in RT-PCR for gene expression

\begin{tabular}{|lll|}
\hline Primer name & Sequence $\mathbf{5}^{\prime} \rightarrow \mathbf{3}^{\prime}$ & T.M. $\left({ }^{\circ} \mathbf{C}\right)$ \\
\hline Ta14S-F1 & ACGACTCAAGCGAGGGGCA & 55 \\
Ta14S-R1 & CGCCTGCTACGCTACAAGGAC & 58 \\
Ta14S-F2 & GTCAATGACCGTTGCAATGTG & 52 \\
Ta14S-R2 & GCCACCACCACCACTGTATG & 56 \\
$\beta$-actin-F & TTTGAAGAGTCGGTGAAGGG & 52 \\
$\beta$-actin-R & TTTCATACAGCAGGCAAGCA & 50 \\
\hline
\end{tabular}

\section{Calculation of relative quantitation}

Data analysis The threshold cycle values were used for assessing the gene expression levels obtained from RT-PCR results. Obtained from relative or comparative qualitative quantitation results of threshold cycle value, the $2^{-\Delta \Delta c t}$ value was used for calculating the gene expression levels (Rao et al., 2013). For each of the samples, the mean of $2^{-\Delta \Delta \mathrm{ct}}$ values of 5 samples taken from the same point was calculated. Representing the gene expression level, $2^{-\Delta \Delta c t}$ was computed using the formula below: $2^{-((\mathrm{a}-\mathrm{b})-(\mathrm{c}-\mathrm{d}))}$; where a is $\mathrm{Ct}$ value obtained from the gene used for each of the samples; $b, \mathrm{Ct}$ value obtained from the gene used for control group; $\mathrm{c}, \mathrm{Ct}$ value obtained from $\beta$-actin gene of each of the samples; $d$, Ct value obtained from $\beta$-actin gene of control group.

\section{RESULTS}

14-3-3 gene family is the protein family regulated as a defense mechanism in case of stress. $2^{-\Delta \Delta c t}$ values, which are significant expressions in the quantitative analysis of gene expression amount, 
were calculated for all dose values of 2,4-D isooctylester and zingerone in Sönmez-2001, Köprü and Altay-2000 wheat seedlings. In wheat samples germinated by exposure to 2,4-D isooctylester herbicide, the level of 14-3-3 gene expression increased in direct proportion to the dose. The lowest gene expression level was obtained at a dose of $0.1 \mathrm{ppm}$, while the highest gene expression level was detected at a dose of $0.5 \mathrm{ppm}$. The highest Ta14S1 gene expression level was detected in Altay-2000 and the lowest in Sönmez-2001.

In all three wheat types, increased 14-3-3 gene expression resulting from 2,4-D isooctylester herbicide stress was found to decrease depending on the zingerone doses applied. A decline in 14-3-3 gene expression level was detected at all doses. The largest decrease was obtained from $0.3 \mathrm{ppm}$ zingerone application. Ta14S1 gene expression levels of Sönmez-2001, Köprü and Altay-2000 types to which 2,4-D isooctyl ester and different doses of zingerone were applied are given in Figure 2, 3 and 4.

Figure 2. Ta14S1 gene expression level obtained from Sönmez-2001 wheat samples

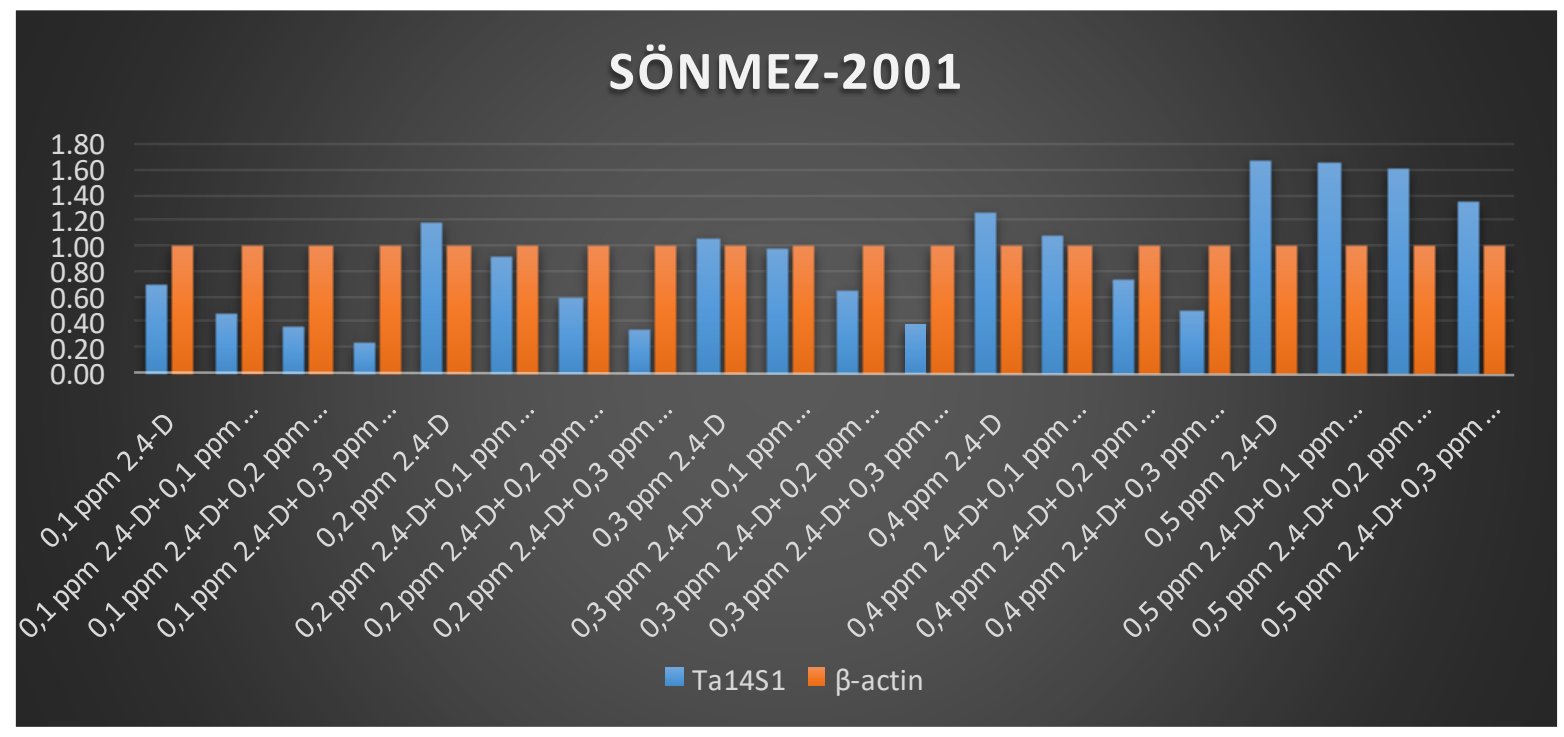


International Journal of Agriculture, Environment and Bioresearch

Vol. 5, No. 05; 2020

ISSN: $2456-8643$

Figure 3. Ta14S1 gene expression level obtained from Köprü wheat samples

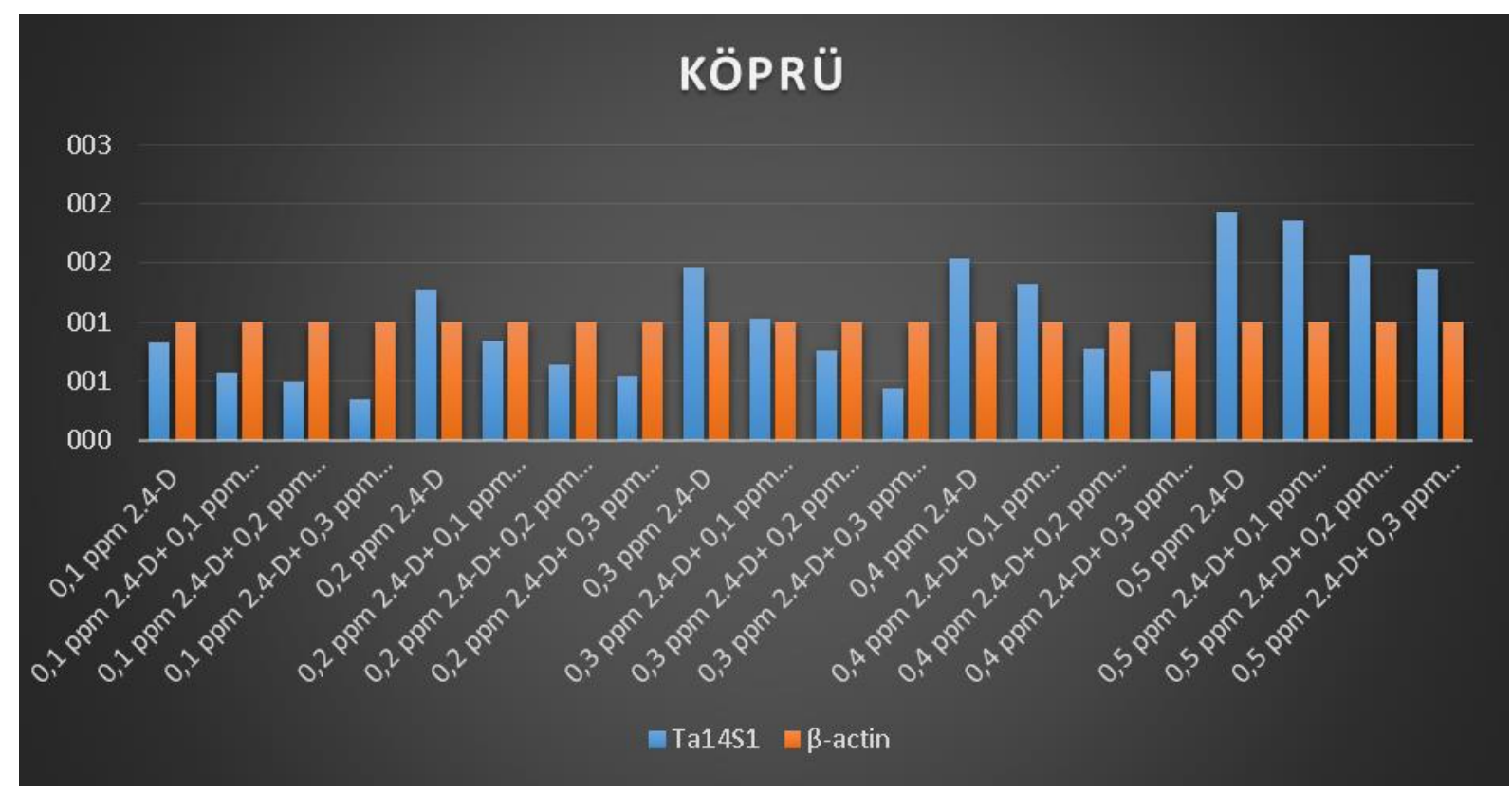

Figure 4. Ta14S1 gene expression level obtained from Altay-2000 wheat samples

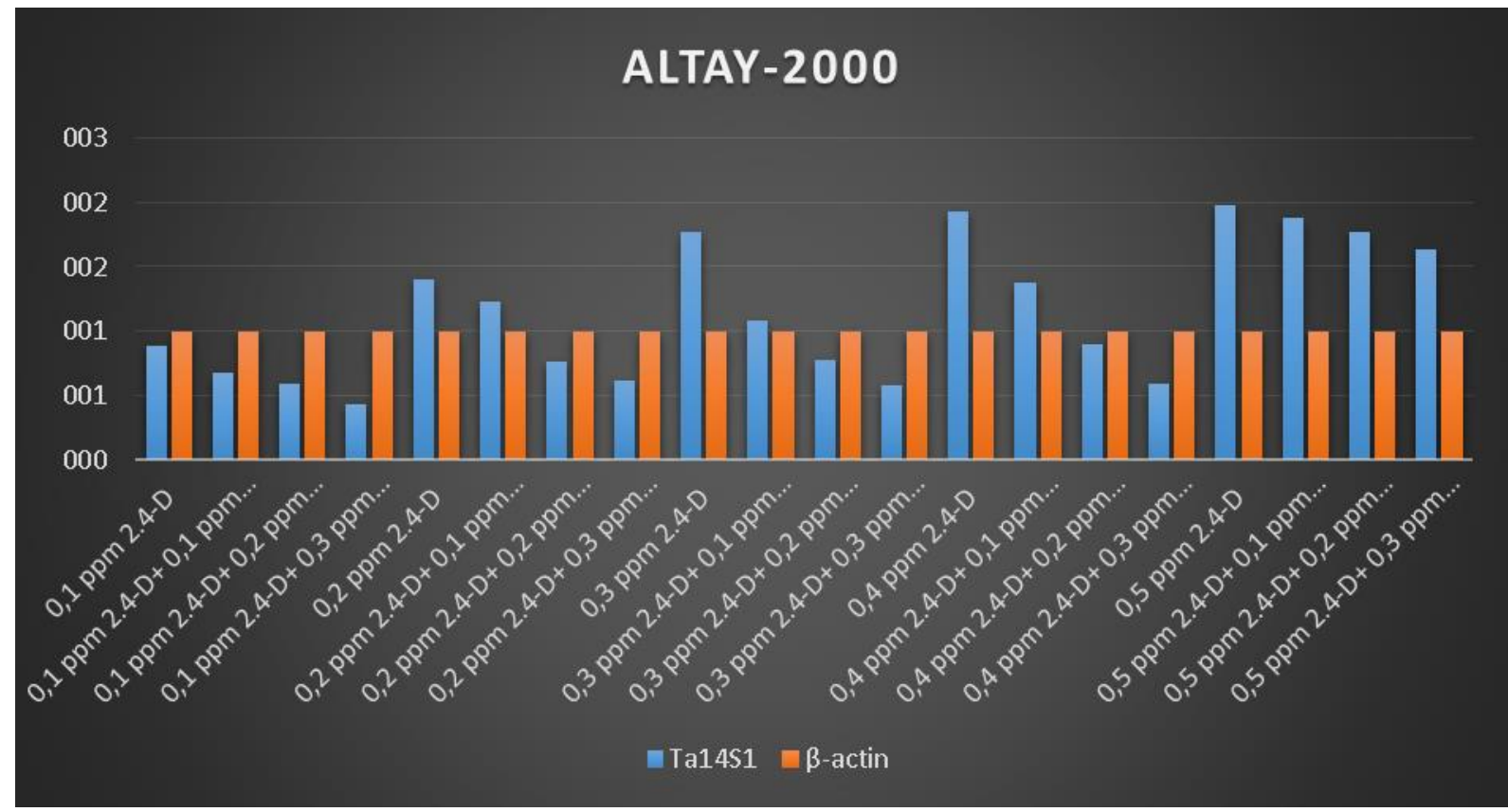


$2^{-\Delta \Delta c t}$ values, which are significant expressions in the quantitative analysis of gene expression amount, were calculated for all dose values of 2,4-D isooctylester and zingerone in Sönmez2001, Köprü and Altay-2000 wheat seedlings. In wheat samples germinated by exposure to 2,4D isooctylester herbicide, the level of 14-3-3 gene expression increased in direct proportion to the dose. The lowest gene expression level was obtained at a dose of $0.1 \mathrm{ppm}$, while the highest gene expression level was detected at a dose of $0.5 \mathrm{ppm}$. The highest Ta14S1 gene expression level was detected in Altay-2000 and the lowest in Sönmez-2001.

The decrease in Ta14S2 gene expression level was detected at all doses. However, in $0.1 \mathrm{ppm}$, $0.2 \mathrm{ppm}$ and $0.3 \mathrm{ppm} 2,4-\mathrm{D}$ isooctylester applications, the reduction in expression level is obvious. The largest decrease in Ta 14S2 expression level was obtained from $0.3 \mathrm{ppm}$ zingerone application. Figure 5, 6 and 7 state the Ta14S2 gene expression levels of the samples belonging to Sönmez-2001, Köprü and Altay-2000 types to which 2,4-D Isooctylester and different doses of zingerone were applied.

Figure 5. Ta14S2 gene expression level obtained from Sönmez-2001 wheat samples

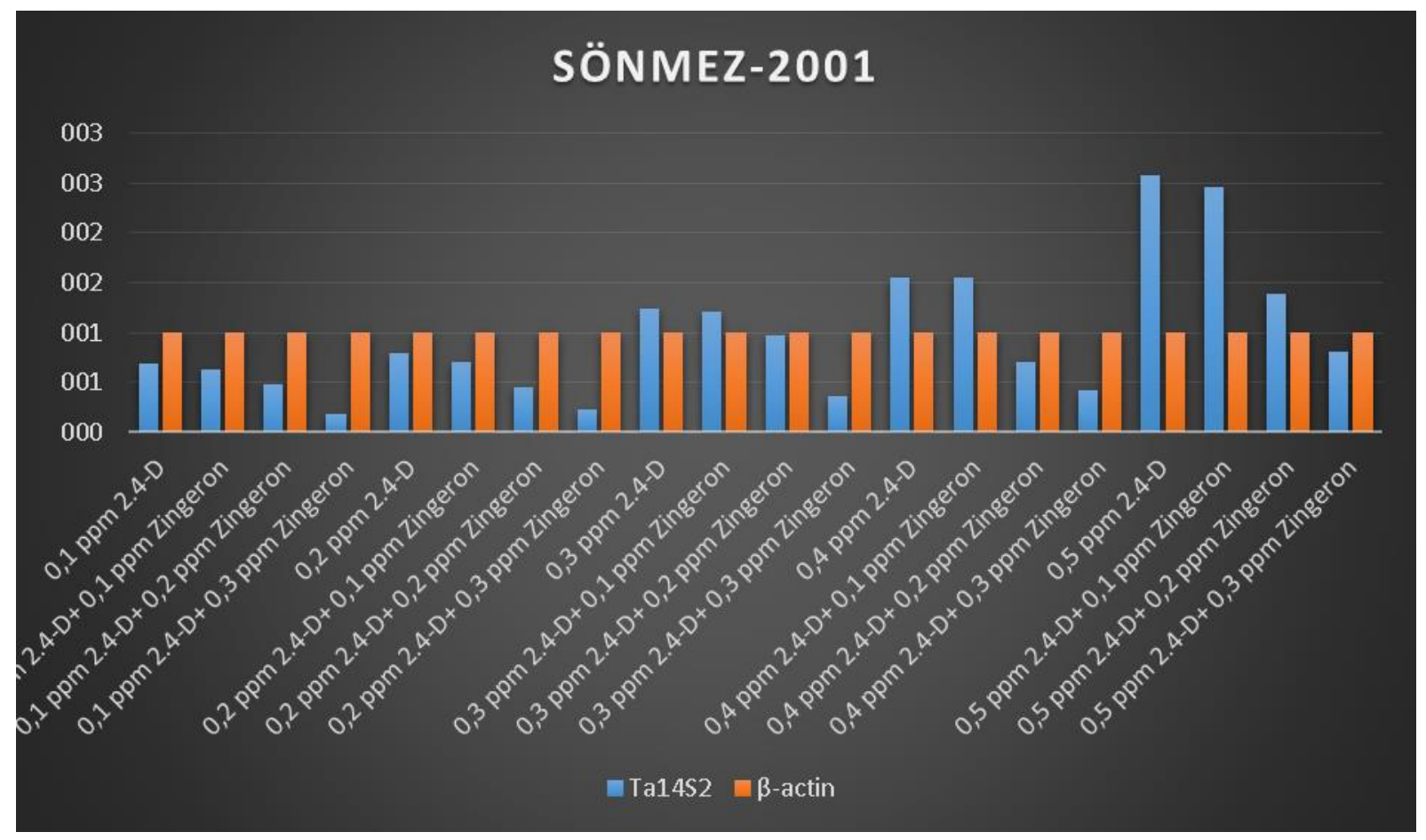


International Journal of Agriculture, Environment and Bioresearch

Vol. 5, No. 05; 2020

ISSN: $2456-8643$

Figure 6. Ta14S2 gene expression level obtained from Köprü wheat samples

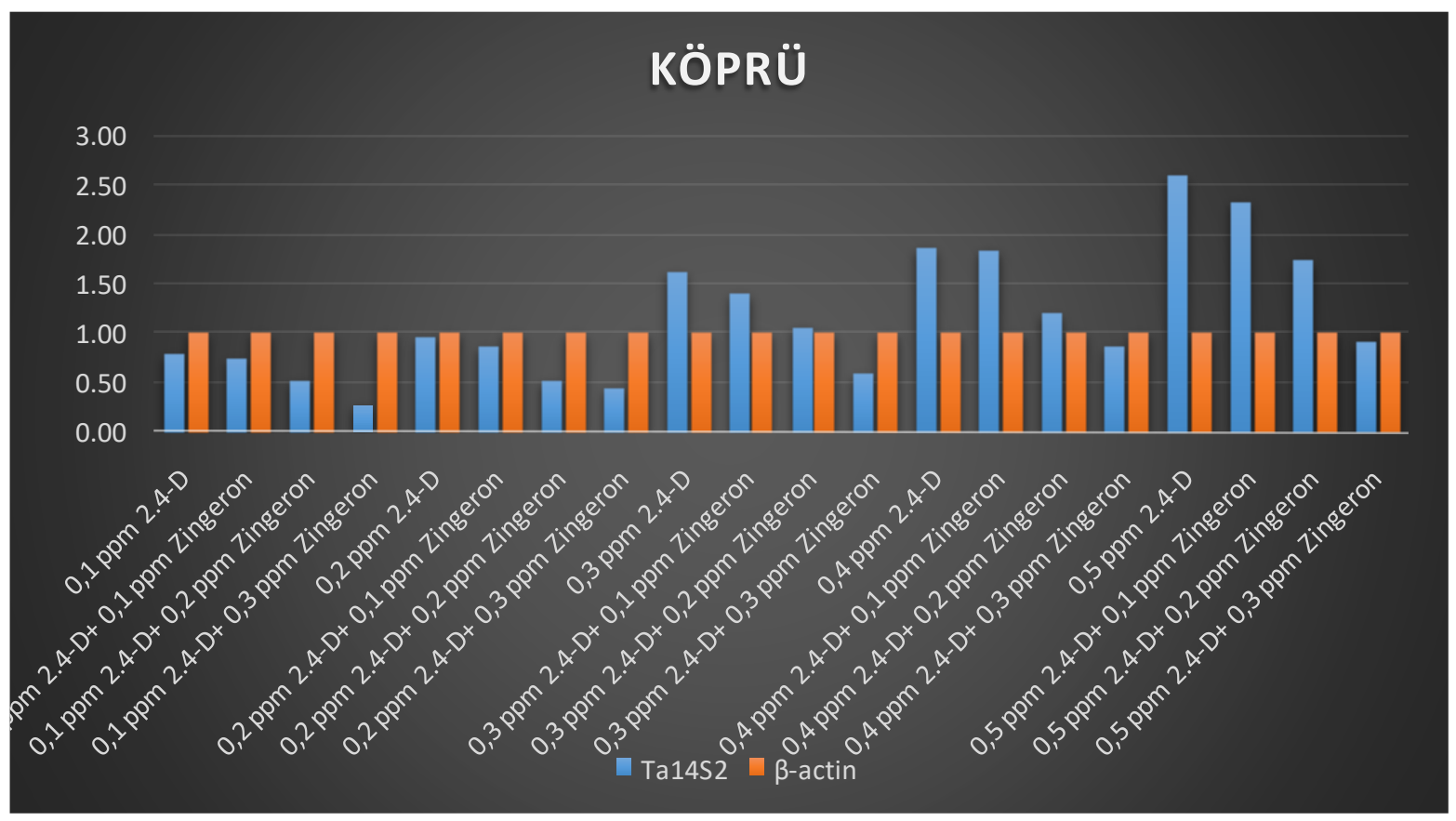

Figure 7. Ta14S1 gene expression level obtained from Altay-2000 wheat samples

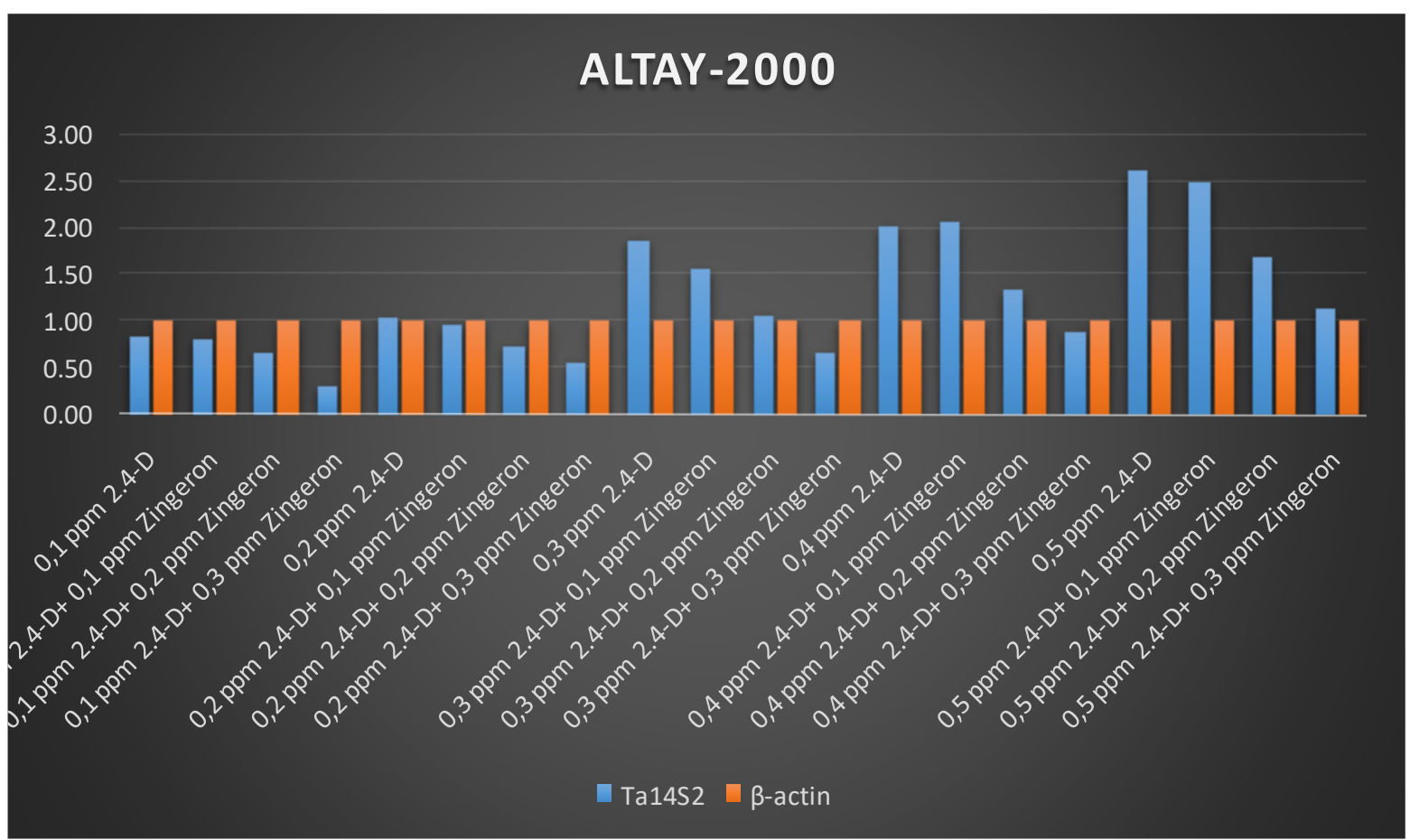


Vol. 5, No. 05; 2020

ISSN: $2456-8643$

\section{DISCUSSION}

The main purpose of agriculture is to obtain the largest possible quantity of high-quality products from the unit area without damaging the ecological balance. Undoubtedly, one of the most important factors limiting this aim is disease, pests and weeds (Topal, 2011). It is reported that the loss of crop caused by weeds is about $32 \%$, and this loss reaches nearly half of the damage caused by all plant protection problems (Aydin and Tursun, 2010). The use of herbicides has become an acceptable approach to keep the weeds in agriculture below specific limit values to reduce product losses in order to meet the food needs of the ever-increasing population of the world. However, continuous and high doses of herbicides usage cause environmental pollution and, thus, stress in plants (Bhadoria, 2011).

Pesticides that are frequently used in agriculture are one of the important anthropogenic practices threatening ecological life. 2,4-D is a type of phenoxy acid herbicide (Gehring et al., 1990). They are moderately stable chemicals and cause a slowdown in the development of the products to which they are applied (Donald et al., 1999). Besides, 2,4-D's mutagenic and genotoxic effect depending on its concentration has been stated in various studies (Pavlica et al., 1991; Enan, 2009).

It is well known that plants respond to environmental cues in a complex and highly coordinated manner at physiological, biochemical and molecular levels (Woodrow et al., 2011; Woodrow et al., 2017). Stress-induced disruption in normal cell functioning requires rapid and broad reprogramming at the molecular level to respond to such adverse conditions (Woodrow et al., 2011; Woodrow et al., 2017; Megha et al., 2018). This reprogramming is based on strict regulation of the expression of stress-sensitive genes, especially at the transcriptional and posttranscriptional levels (Jeknić et al., 2014; Shriram et al., 2016; Khare et al., 2018). The effective resistance of plants depends on the induction of stress-related genes and the synthesis of proteins by their defensive roles (Vinocur and Altman, 2005). Plants have developed complex mechanisms to detect and respond to various abiotic and biotic stresses such as drought, salinity, adverse temperature, heavy metal toxicity and nutrient deficiency (Campo et al., 2012; Zwackand Rashotte, 2015). It has been reported that the 14-3-3 protein group, in addition to controlling plant development and metabolism (Obidiegwu et al., 2015), are also involved in molecular networks which protect plant cells from biotic and abiotic stresses and play an important role in the plant defense response (Chelysheva et al., 1999; Roberts et al., 2002; Chen et al., 2006; Denison Fiona et al., 2011).

There are various studies that examine the effect of different stress types on gene expression. For example, Xie et al. (Xie et al.,2017) stated in their study on Coprinus atramentarius that the level of 14-3-3 gene expression depends on $\mathrm{Cd}$ intensity, and there is a correlation between $\mathrm{Cd}$ exposure and 14-3-3 transcriptional regulation. Owen et al. (2012) found a rapid 14-3-3 induction in seaweeds exposed to different doses of $\mathrm{Cu}$, and it was also reported that 14-3-3s played an important role in $\mathrm{Cu}$ tolerance (Halland Williams, 2003; Chen et al., 2015). In the study conducted to determine the role of $\mathrm{Cu}$ in 14-3-3 transcriptional regulation, it was emphasized that there is a change in gene expression levels depending on different densities in 
potato (Solanum tuberosum) (Aksamit et al., 2005). A high increase in 14-3-3 protein expression was detected on Coprinus atramentarius exposed to $\mathrm{Pb}$ heavy metal stress (Wei et al., 2016).

The gene expression levels in wheat seedlings under the 2,4-D herbicide stress of this protein group, which has an important role for plant development and defense, were determined, and the size of the stress caused by the 2,4-D herbicide was analyzed. For this purpose, $2^{-\Delta \Delta \mathrm{Ct}}$ values which are an effective parameter in calculating the level of gene expression were calculated using the threshold cycle value obtained from the samples. The evaluation results were obtained by the comparison of the $\beta$ - actin housekeeping gene expression level, where the level of 14-3-3 gene expression increased depending on the dose of the 2,4-D herbicide. However, it has been determined that zingerone application causes a decrease in gene expression. The decrease in gene expression may be due to zingerone's reduction of stress caused by the 2,4-D herbicide.

In addition, it has been determined that zingerone reduces the stress level caused by the herbicide in wheat samples. The conclusion of our study supports the statement that abiotic stress is a complex progression (Khaksefidi et al., 2015).

It has been determined that the level of stress caused by the herbicide in wheat types is different. Ginger extract zingerone has been found to play a protective role against the genotoxic effect caused by the herbicide. In addition, it has been determined that Sönmez-2001 type has a higher tolerance to herbicide stress than Altay-2000 and Köprü wheat types.

\section{SUGGESTIONS}

As determined in our study results, there is a need for herbicides with high selectivity on weeds. Moreover, determining what is the effect of stress occurring in plants on the synthesis of proteins represents an important question mark. Nevertheless, it will be useful to reveal the effect of herbicide applications on plant nominal yield.

\section{ACKNOWLEDGMENT}

This study includes FBA-2019-606 projects supported by Erzincan Binali Yıldırım University BAP Coordination Unit. We would like to thank NBC Agriculture and Seed / Eskişehir-Turkey.

\section{CORRESPONDING AUTHOR}

Hüseyin BULUT

Erzincan Binali Yıldırım University Vocational School of Health Services, 24100 Erzincan / Turkey

E-mail: $\underline{\text { huseyinbulut@erzincan.edu.tr }}$ 
Vol. 5, No. 05; 2020

ISSN: $2456-8643$

\section{REFERENCES}

AFM (Republic of Turkey Ministry of Agriculture and Forestry) (2020). https://www.tarim orman . gov.tr/Konular/Bitkisel-Uretim

Aksamit, A. A., K. Jacek, S. Marcin, L. Jan, S. (2005). The 14-3-3 Gene Expression Specificity in Response to Stress is Promoter-Dependent, Plant and Cell Physiology, 46 (10):16351645 .

Avcı, M.Ç. (2009). Investigation of the Stamina Problems of phalaris brachystchys Link (Bloody Meadow) Against Some Wheat Herbicides in Çukurova Region Wheat Plantation Areas. Cukurova University Institute of Science Master's Thesis, Adana.

Aydın, O. And Tursun, N. (2010). Determination of Allelopathic Effects of Some Plant Originated Essential Oils on Germination and Emergence of Some Weed Seeds. KSU J. Nat. Sci., 13(1):11-17.

Bhadoria, B.P.S. (2011). Allelopathy: A Natural Way Towards Weed Management. Ajea 1(1):720.

Brenchley, R., Spannagl, M., Hall, N. (2012). Analysis of the bread wheat genome using whole-genome shotgun sequencing, Nature, 491:705-710.

Campo, MT, Fouad, H., Solís-Bravo, M.M., Sánchez-Uriz, M.A., Mahíllo-Fernández, I., Esteban, J. (2012). Cost-effectiveness of different screening strategies (single or dual) for the diagnosis of tuberculosis infection in healthcare workers, Infect Control Hosp Epidemiology, 33(12):1226-1234.

Chelysheva, V.V., Smolenskaya, I.N., Trofimova, M.C., Babakov, A.V., Muromtsev, G.S. (1999). Role of the 14-3-3 proteins in the regulation of H+-ATPase activity in the plasma membrane of suspension-cultured sugar beet cells under cold stress, FEBS Letters, 456:2226.

Chen, F., Li, Q., Sun, L., He, Z. (2006). The rice 14-3-3 gene family and its involvement in responses to biotic and abiotic stress, DNA Research, 13:53-63.

Chen, J., Li, X., Wang, D., Li, L., Zhou, H., Liu, Z., Wu, J., Wang, P., Jiang, X., Fabrice, M.R., Zhang, S., Wu, J. (2015). Identification and testing of reference genes for gene expression analysis in pollen of Pyrus bretschneideri, Scientia Horticulturae, 190:43-56.

Cheng, H., Marín-Sáez, J., Romero-González, R., Frenich, A.G. (2017). Simultaneous determination of atropine and scopolamine in buckwheat and related products using modified QuEChERS and liquid chromatography tandem mass spectrometry. Food Chem., 218:173-180.

Denison Fiona, C., Anna-Lisa, P., Agata, K.Z., Robert, J.F. (2011). 14-3-3 proteins in plant physiology, Seminars in Cell \& Developmental Biology, Volume 22 (7):720-727. 
Donald, D.B., Syrgiannis, J., Hunter, F., Weiss, G. (1999). Agricultural pesticides threaten the ecological integrity of northern prairie wetlands. Sci. Total Environ. Jul., 23:173-81.

Enan, M.R. (2009). Genotoxicity of the herbicide 2,4-Dichlorophenoxyacetic acid (2,4-D): higher plants as monitoring systems. JTFE, 25:147-155.

EUM (Environment and Urban Ministry) (2019). https://environmentalindicators.csb.gov. tr/pesticide-use-i-86060.

Gehring, C.A., Irving, H.R., Parish, R.W. (1990). Effects of auxin and abscisic acid on cytosolic calcium and pH in plant cells. Proc. Natl. Acad. Sci. USA, 87:9645-9649.

Hall, J.L. and Williams, L.E. (2003). Transition metal transporters in plants, Journal Explorer Botany, 54(393): 2601-2613.

Jeknić, Z., Pillman, K.A., Dhillon, T., Skinner, J.S., Veisz, O., Cuesta-Marcos, A., Hayes, P.M., Jacobs, A.K., Chen, T.H.H., Stockinger, E.J. (2014). Hv-CBF2A overexpression in barley accelerates COR gene transcript accumulation and acquisition of freezing tolerance during cold acclimation. Plant Mol. Biol., 84:67-82, 10.1007/s11103-013-0119-z

Khaksefidi, R.E., Mirlohi, S., Khalaji F., Fakhari, Z., Shiran, B., Fallahi, H., Rafiei, F., Budak, H., Ebrahimie, E. (2015). Differential Expression of Seven Conserved microRNAs in Response to Abiotic Stress and Their Regulatory Network in Helianthus Annuus. Front Plant Sci, 17;6:741. doi: 10.3389/fpls.2015.00741. eCollection 2015.

Khare, T., Shriram, V., Kumar, V. (2018). RNAi technology: the role in development of abiotic stress-tolerant crops. Biochemical, Physiological and Molecular Avenues for Combating Abiotic Stress Tolerance in Plants, Elsevier, 117-133, 10.1016/B978-0-12-8130667.00008-5

Köksel, H., Sivri, D., Özboy, Ö., Başman, A., Karacan, H. (2000). Grain Laboratory Manual, Ceylan Publications, Ankara.

Liu, L., Wang, Y.X., Zhou, J., Long, F., Sun, H.W., Liu, Y., Chen, Y.Z., Jiang, C.L. (2005). Rapid non-genomic inhibitory effects of glucocorticoids on human neutrophil degranulation, Inflamm Research, 54(1):37-41.

Malarkodi, C., Rajeshkumar, S., Annadurai, G. (2017). Detection of environmentally hazardous pesticide in fruit and vegetable samples using gold nanoparticles. Food Control, 80:11-18.

Megha, S., Basu U., Kav, N.N.V. (2018). Regulation of low temperature stress in plants by microRNAs Plant Cell Environ., 41:1-15, 10.1111/pce.12956.

Moreno-González, D., Pérez-Ortega, P., Gilbert-López, B., Molina-Díaz, A., García-Reyes, J.F., Fernández-Alba, A.R. (2017). Evaluation of nanoflow liquid chromatography high resolution mass spectrometry for pesticide residue analysis in food. J. Chromatogr. A, 1512:78-87. 
Obidiegwu, J.E., Glenn, J.B., Hamlyn, G.J. and Ankush, P. (2015). Coping with drought: stress and adaptive responses in potato and perspectives for improvement, Front Plant Science, 6:542, doi: 10.3389/fpls.2015.00542.

Owen, J.R., Morris, C.A., Nicolaus, B., Harwood, J.L., Kille, P. (2012). Induction of expression of a 14-3-3 gene in response to copper exposure in the marine alga, Fucus vesiculosus, Ecotoxicology, 21(1):124-138.

Pavlica, M., Papes, D. and Nagy, B. (1991). 2,4-Dichlorophenoxyacetic acid causes chromatin and chromosome abnormalities in plant cells and mutation in cultured mammalian cells. Mutat Res., 263:77-81.

Rao, X., Xuelin, H., Zhicheng, Z. and Xin, L. (2013). An improvement of the $2^{\wedge}$ (-delta delta CT) method for quantitative real-time polymerase chain reaction data analysis, Biostat Bioinforma Biomath, 3 (3):71-85.

Rastogi, L., Dash, K., Ballal, A. (2017). Selective colorimetric/visual detection of $\mathrm{Al}^{3}+$ in ground water using ascorbic acid capped gold nanoparticles. Sensor Actuat B-Chem, 248: 124132.

Roberts, M.R., Salinas, J., Collinge, D.B. (2002). 14-3-3 proteins and the response to abiotic and biotic stress, Plant Molecular Biology, 50 (6):1031-1039.

Shriram, V., Kumar, V., Devarumath, R.M., Khare, T.S., Wani S.H. (2016). MicroRNAs as potential targets for abiotic stress tolerance in plants. Front. Plant Sci., 7:8173389$8173817,10.3389 /$ fpls.2016.00817

Topal, S. (2011). Allelokimyasalların herbisit etkileri. Dumlupınar Üniversitesi, Fen Bilimleri Enstitüsü Dergisi, 25:1302-3055.

TSI (Turkish Statistical Institue) (2019). http://www.tuik.gov.tr/UstMenu.do?Metod =temelist

TSI (Turkish Statistical Institue) (2016). http://www.turkstat.gov.tr/UstMenu.do?metod= temelist., Son Erişim Tarihi 12.08.2017.

Vinocur, B., Altman, A. (2005). Recent advances in engineering plant tolerance to abiotic stress: $\begin{array}{llll}\text { achievements and limitations, } & \text { Biotechnology, } 163-132 .\end{array}$

Wei, J., Zhang, Y., Yu, T.Y., Sadre-Bazzaz, K., Rudolph, M.J., Amodeo, G.A., Symington, L.S., Walz, T., Tong, L. (2016). A unified molecular mechanism for the regulation of acetylCoA carboxylase by phosphorylation, Cell Discovery, 2:16044, doi:10.1038/ celldisc.2016.44.

Woodrow, P., Ciarmiello, L.F., Annunziata, M.G., Pacifico, S., Iannuzzi, F., Mirto, A., D'Amelia, L., Dell'Aversana, E., Piccolella, S., Fuggi, A., Carillo, P. (2017). Durum wheat seedling responses to simultaneous high light and salinity involve a fine reconfiguration of amino acids and carbohydrate metabolism Physiol. Plant., 159:290-312, 10.1111/ppl.12513. 
Woodrow, P., Pontecorvo, G., Ciarmiello, L.F., Fuggi, A., Carillo, P. (2011). Ttd1a promoter is involved in DNA-protein binding by salt and light stresses. Mol. Biol. Rep., 38:37873794, 10.1007/s11033-010-0494-3.

Xie, C., Liujie, H., Yongzhu, Y., Dunxiu, L., Xingyong, Y. (2017). Accumulation and tolerance to cadmium heavy metal ions and induction of 14-3-3 gene expression in response to cadmium exposure in Coprinus atramentarius, Microbiological Research, 196:1-6.

Zwack, P.J. and Rashotte, A.M. (2015). Interactions between cytokinin signalling and abiotic stress responses, Journal Explorer Botany, 66: 4863-4871. 